\title{
Contamination Risk in Indonesian Youtube Videos on Personal Protective Equipment for Corona Virus Disease
}

\author{
Laksita Barbara ${ }^{1}$, Mareta Dea Rosaline ${ }^{2}$, Akhiyan Hadi Susanto ${ }^{3}$ \\ 1,2Nursing Program, Faculty of Health Science, Universitas Pembangunan Nasional Jakarta, Indonesia \\ ${ }^{3}$ Basic Nursing Department, Faculty of Medicine, University of Brawijaya, Indonesia \\ 1Jl. Raya Limo, Kecamatan Limo, Kota Depok, 16515 \\ Corresponding author: barbara.laksita@upnvj.ac.id
}

Submitted: 20"th April 2021, Revised: 9th December 2021, Accepted: 14th December 2021

\begin{abstract}
There are numbers of Indonesian Youtube Videos that show steps to wear and remove Personal Protective Equipment (PPE) for Corona Virus Disease (COVID19). However, the conformity with the current guidelines remains unknown. This paper aims to determine the validity of these videos based on the World Health Organization (WHO) guidelines. We searched on the Youtube website for videos in donning and doffing PPE for droplet precaution and selected the videos using inclusion and exclusion criteria. Included videos were then evaluated with a checklist derived from WHO course on donning and doffing PPE for COVID-19 and WHO recommendation on PPE for Covid-19. The search that was undertaken resulted in 66 videos, and 40 videos were included for evaluation. There is no significant difference in the donning and doffing score between account types (personal, organizational/ institutional, news). The average number of viewers of all videos is more than 2700 viewers. The average score of donning is less than $70 \%$ of the total score, and the average doffing score is under $65 \%$. The vast majority of the videos do not follow the WHO recommendation on the PPE type and use more equipment than recommended. There are several contamination risks shown by the videos. Indonesian Youtube videos on PPE procedures for COVID-19 must be selected carefully to be used as an instructional or educational media since most of it presents a high risk of cross-contamination.
\end{abstract}

Keyword: personal protective equipment, audiovisual, cross-contamination, training

\section{Abstrak}

Terdapat video dalam Bahasa Indonesia yang terkait cara memakai dan melepaskan Alat Pelindung Diri (APD) untuk Corona Virus Disease (COVID19). Namun, kesesuaian video terhadap pedoman terkini belum diketahui. Penelitian ini bertujuan untuk menentukan validitas video berdasarkan pedoman World Health Organization. Kami menelusuri Youtube untuk memperoleh video instruksi mengenakan dan melepas APD pencegahan kontaminasi droplet dan menyeleksi video tersebut berdasarkan kriteria inklusi dan eksklusi. Video yang telah diseleksi kemudian dievaluasi menggunakan checklist yang diturunkan dari langkah-langkah yang ditunjukan dalam kursus APD COVID-19 yang disediakan oleh WHO, serta rekomendasi APD dari WHO. Penelusuran Youtube menampilkan 66 video, dan dipilih 40 video yang sesuai dengan kriteria kelayakan. Tidak terdapat perbedaan signifikan dalam skor mengenakan dan melepaskan APD antara akun personal, organisasi/institusi, dan berita. Rata-rata jumlah penonton video adalah lebih dari 2700. Skor rata-rata pemakaian APD kurang dari 70\% dari skor total, dan skor pelepasan APD kurang dari 65\%. Sebagian besar video tidak mengikuti rekomendasi WHO dalam pemilihan tipe PPE dan menggunakan alat yang lebih banyak dari yang direkomendasikan. Terdapat sejumlah risiko kontaminasi yang dapat diobservasi dari langkah-langkah yang ditunjukan dalam video. Video Youtube prosedur APD untuk COVID-19 perlu diseleksi dengan cermat untuk digunakan sebagai media instruksi maupun pendidikan karena sebagian besar menunjukan risiko tinggi kontaminasi silang.

Kata Kunci: alat pelindung diri, audiovisual, kontaminasi silang, pelatiban

\section{Introduction}

Coronavirus disease, or commonly known as COVID19, has become a global pandemic since March 11, 2020 (1). The virus spreads through droplets of people who suffer from the disease or carry the virus in their body (2). The spread of the disease in Indonesia was first announced on March 2, 2020, and the case has increased rapidly since then (3). Indonesia is one of the countries which has the highest death rate in South-East Asia due to COVID19 (4). The mortality of healthcare workers (HCWs) in Indonesia is more than $6 \%$ of total death (5). The high number of dead in the healthcare workers has become an issue since hospitals are in the highest demand. 
Health care workers are especially susceptible to coronavirus transmission since they have a high risk of patients' body fluid exposure. This transmission route requires healthcare workers who take care of the patients to practice standard precautions for droplet transmission. Standard personal protective equipment (PPE) and the proper procedure are paramount to provide health care services. However, there are drawbacks in an attempt to protect healthcare workers. The government is managing the PPE supply for hospitals and other health care services around the country (6). In addition to the supply issue, we also need to identify whether the procedure of donning and doffing the PPE is appropriate.

The World Health Organization (WHO) has published recommendations and instructional videos in PPE for taking care of patients with COVID-19 (7). However, there is no Indonesian video on the PPE procedures available on The Ministry of Health of Indonesia Republic website or WHO website. Videos could help meet psychomotor learning objectives such as donning and doffing PPE for the Covid-19 case. Youtube is an open source for accessing videos. There are many videos made by personals and institutions in Indonesia about steps to wear and remove PPE in COVID19 published on the Youtube page. However, the validity of these videos confronted with WHO guidelines and recommendations in the COVID-19 pandemic remains unknown. This paper aims to determine the validity of Indonesian Youtube videos on the Covid-19 PPE procedures based on the WHO guidelines and recommendations.

\section{Methods}

We searched on the Youtube website for videos in donning and doffing PPE for droplet precaution on May 19, 2020. We use the keyword in Indonesian "pemakaian pelepasan alat pelindung diri" which means "wearing and removing personal protective equipment". The search resulted in 66 videos. The videos were selected for evaluation based on the inclusion and exclusion criteria. Videos uploaded between January 11 to May 19, 2020, containing instructions and directions on wearing or removing PPE for droplet precaution, and delivered in the Indonesian language were included. Videos showing product brand advertisement, humor or entertainment videos, case reports, or news only without instruction, and showing the process without written or verbal instruction were excluded.

Included videos were then evaluated with a checklist derived from WHO course on donning and doffing PPE for COVID-19 and WHO recommendation on PPE for Covid-19. We evaluated the steps that were taken and the type of PPE that was used on the video. We also extracted information on when the video was uploaded, the video link, the account uploaded the video, video duration, and the viewers' number. The steps of the instruction were evaluated by two reviewers independently. We evaluated the donning and the doffing procedure separately using the donning procedure checklist and the doffing procedure checklist. We gave 0 points to 2 points for each step based on the consideration of whether the step is shown, shown correctly, and sequentially. The disagreement between the two reviewers was discussed. When an agreement could not be achieved, we involved a third party, an infection control expert, to decide on the scoring.

The data were analyzed using Statistical Package for Social Sciences for Windows software (Version 25; SPSS, Inc., Chicago, IL). The procedures' scores were analyzed for the median, mean, and interquartile range, and the nominal data were analyzed for the frequency and percentage. ANOVA test was done to analyze the difference of means between groups for donning and doffing scores (personal, organizational/institution, and news program accounts). Kruskal-Walli's test was performed to analyze the difference in the number of views between groups.

\section{Results and Discussion}

Form the search undertaken on the Youtube site using the keywords, 66 videos appeared. We excluded 26 videos with most of the videos failing to show the procedures' written or verbal instructions. We extracted data from 40 videos and evaluated the donning and doffing scores using checklists based on the WHO recommendation. Organization/ institution accounts uploaded more than half of the included videos (Table 1). Coveralls are used in $85 \%$ of the videos with two videos showing both types of PPE (gown and coverall). Nearly 50\% of the videos were uploaded in April, and only $10 \%$ was uploaded in February 2020. 
Table 1.

The distribution of viewers and scores of the included videos between groups

\begin{tabular}{ccccc}
\hline Account type & $\mathbf{N}$ & Number of viewers & Donning Score & Doffing score \\
\hline Personal & 15 & $2575.40(19-8827)$ & $11.42(7-14)$ & $8.44(4-12)$ \\
Organization/ Institution & 22 & $2345.91(13-14020)$ & $11.17(8-15)$ & $9.32(6-12)$ \\
News Program & 3 & $6279.00(426-17451)$ & $10.00(8-11)$ & $9.00(8-10)$ \\
$p$ value & - & 0.171 & 0.605 & 0.562 \\
\hline
\end{tabular}

Videos that were uploaded by personal accounts have the highest scores' mean of the other two account types. However, the difference is not significant ( $p=0.605$, CI 95\%). The highest score is shown by a video from a hospital account that obtained more than $93 \%$ of the total score in donning PPE, followed by three personal accounts. On the other hand, the lowest score is shown by a personal account. Two videos from official health provider accounts are only scored 6 or $50 \%$ of the total score. That is to say, the type of account does not influence the consistency of the video with WHO guidelines.

The average number of viewers of all the included videos is more than 2700 viewers. The number of viewers is not significantly affected by the type of account $(p=0.562$, CI 95\%). The highest number of viewers is gathered by a news program account with more than 17.000 viewers on data extraction (May 19, 2020), which is scored 11 on donning and not showing doffing procedure. On the other hand, the highest scored video in donning has only 361 viewers.

Table 2.

Frequency of Donning and Doffing Score

\begin{tabular}{llrr}
\hline & & Donning score & Doffing Score \\
\hline $\mathrm{N}$ & Valid & 33 & 30 \\
& Missing & 7 & 10 \\
Mean & 11.15 & 9.03 \\
Median & 11.00 & 9.00 \\
Mode & 11 & 8 \\
Std. Deviation & 2.138 & 1.956 \\
Variance & 4.570 & 3.826 \\
Range & 8 & 8 \\
Minimum & 7 & 4 \\
Maximum & 15 & 12 \\
\hline
\end{tabular}

Table 2 depicts the average score of the videos which show the donning process was 11.15 out of $16(69.7 \%)$. The average of the videos which show doffing procedure were scored $64.5 \%(9.03$ out of 14). The highest score for donning is $93.8 \%$ which is achieved by an official account of a hospital. In Doffing procedure, three accounts get the highest score $(85.7 \%)$, two of which are official accounts.

Table 3.

The distribution of scores for each step of the donning procedure

\begin{tabular}{llll}
\hline \multicolumn{1}{c}{ Step } & \multicolumn{1}{c}{ Not Done } & \multicolumn{1}{c}{$\begin{array}{c}\text { Done } \\
\text { Incorrectly }\end{array}$} & \multicolumn{1}{c}{$\begin{array}{c}\text { Done } \\
\text { Correctly }\end{array}$} \\
\hline Equipment preparation & - & $6(18.2 \%)$ & $27(81,8 \%)$ \\
Removing personal items & $22(66.7 \%)$ & - & $11(33.3 \%)$ \\
Performing hand hygiene & $1(3 \%)$ & - & $32(96.9 \%)$ \\
Checking the integrity of the gown & $31(93.9 \%)$ & $1(3 \%)$ & $1(3 \%)$ \\
Wearing the gown & - & $10(30.3 \%)$ & $23(69.7 \%)$ \\
Wearing the mask & $1(3 \%)$ & $24(72.7 \%)$ & $8(24.2 \%)$ \\
Wearing the goggles & - & $6(18.2 \%)$ & $27(81.8 \%)$ \\
Wearing the gloves & - & $3(9.1 \%)$ & $30(90.9 \%)$ \\
\hline
\end{tabular}


Table 3 shows that the step that is often missed from the donning procedure is checking the PPE's integrity, followed by removing personal items. Only eight out of 33 videos show a correct way of putting on the surgical mask or respirator. Performing hand hygiene is the step most of the videos perform correctly, followed by wearing the gloves.

Table 4.

The distribution of scores for each step of the doffing procedure

\begin{tabular}{llll}
\hline \multicolumn{1}{c}{ Step } & Not Done & \multicolumn{1}{c}{$\begin{array}{c}\text { Done } \\
\text { Incorrectly }\end{array}$} & \multicolumn{1}{c}{$\begin{array}{c}\text { Done } \\
\text { Correctly }\end{array}$} \\
\hline Using assistance or a mirror & $28(93.3 \%)$ & $1(3.3 \%)$ & $1(3.3 \%)$ \\
Removing the gloves & - & $20(66.7 \%)$ & $10(33.3 \%)$ \\
Removing the gown & - & $21(70 \%)$ & $9(30 \%)$ \\
Performing hand hygiene & $7(23.3 \%)$ & $1(3.3 \%)$ & $22(73.3 \%)$ \\
Removing the goggles & - & $21(70 \%)$ & $9(30 \%)$ \\
Removing the mask & - & $13(43.3 \%)$ & $17(56.7 \%)$ \\
Performing hand hygiene & $1(3.3 \%)$ & - & $29(96.7 \%)$ \\
\hline
\end{tabular}

Having a colleague observing the removal procedure or performing it in front of the mirror is a step that is not presented or explained in most videos (Table 4). Seventy percent of the doffing videos failed to present the proper way to remove the gown and remove the goggles.

Most videos on PPE are uploaded by organization or institution accounts (Table 1) despite the openness of Youtube platform. This should be an opportunity for HCWs to obtain a reliable source of audio-visual instruction in wearing and removing PPE. However, the videos' credential is not related significantly with the conformity to the guideline. In contrast with this finding, a study investigating the conformity of Youtube video to the CPR guidelines shows that organizational accounts acquire the highest validity (8). This difference in the results could be related to the videos from personal accounts included in this study might be created by hospitals or official organizations. This issue might be related to the absence of the organization official Youtube accounts. Delivering health information through social does not appear to have been done much by the organizations or government in Indonesia. For instance, more than half of the health offices in Indonesia do not have official social media accounts (9). In defiance of the average score, the highest score is gathered by an organization official account, whereas the lowest score is from a personal account. This emphasizes the role of organization and health institutions in providing reliable information in social media platform.

The credential of an account in a social media platform is an important consideration for the audience to trust the information. A study evaluating Youtube videos accuracy on resuscitation suggests that videos uploaded by personal accounts are less likely to be downloaded (10). On the other hand, we found that the account type does not influence the number of viewers. In this case, the viewers might have considered other elements of the videos to evaluate the credential since there are some videos that use a logo or watermark of organizations or institutions. However, with a large number of videos on PPE for COVID19, filtering for official accounts could help the HCWs in deciding efficiently which video to follow.

\section{The Procedures' Validity}

Average videos only follow less than $70 \%$ of the WHO guideline on donning the PPE for COVID 19 cases (Table 2). The WHO recommends ensuring that each of the equipment is in a good condition before putting on PPE (11). The PPE defect could result in a higher risk of contamination since PPE offers protection from patients' body fluid with its impermeability(12). That is to say, if HCWs found that the PPE is not intact, they should replace it with the new one. Thus, an instruction video needs to show this step to know when and how to check their PPE condition.

The most performed fault in the videos is not adjusting the mask's shape or checking the respirator's seal. Respirator use is urged base on the WHO recommendation, especially in aerosol- 
generating procedures (AGPs) (13). The lack of instruction in seal check for a respirator is also discussed in the previous research, which shows that Indonesia does not instruct clearly in performing seal tests for respirator use (14). Performing a negative and positive pressure test when wearing a respirator is essential to ensure that the mask is working correctly to prevent transmission through the respiratory tract. As critical as PPE's proper wearing, the doffing process could be a source of transmission since the PPE is now presumably contaminated. Numbers of studies suggest that mistakes in removing the PPE process are frequent and resulting in contamination to the HCWs (15-17). Thus, videos on removing the PPE should be performed precisely and appropriately.

Most videos show contamination risks in removing the protective suit, especially coverall. Those videos show the possibility of cross-contamination from the gloves to the inner clothes. The gloves were used to unzip the coverall and removing the hood. The procedure in removing coveralls is different from removing gown. However, both steps should be done based on the same fundamentals, avoiding contamination to clothes and face. The high number of coverall's improper removal process is in line with the previous study findings, which shows that health care workers face more difficulty in removing coverall $(17,18)$. The complexity of removing the coverall might result in the lack of compliance with the guidelines; hence, a higher risk of contamination than gown (19). The coverall's front area is the most contaminated since it might be exposed to the patients' droplets or body fluids. Thus, unzipping the coverall contaminates the gloves, and the gloves should not be used to roll out the coverall from inside. If a coverall is used, the standard procedure should be followed. The procedure includes steps from taking off the hoodie, unzipping the front zipper, and pulling the upper part of the coverall together with the gloves (20). Thus, the contaminated gloves will not be used to roll the coverall's bottom part, which consequently prevents the contamination of the inner clothes. Using zoomed visualization and a clear instruction might improve the delivery of the message to prevent contamination.

\section{The Choice of PPE}

Eighty-five percent of the included videos use a coverall as protective equipment instead of a gown. This PPE choice is different than what the WHO has recommended. The coverall's choice might be influenced by the national COVID19 Task Force recommendation stating that coverall could be used for level 3 protection in COVID-19 cases (21). Several countries also recommend the use of coverall as an alternative protective suit based on some considerations $(22,23)$. It is understandable since a coverall offers more concealment compared to a gown. However, coveralls have drawbacks such as heat that can be developed quickly and inconvenient in the donning and doffing (18). A study shows that errors are more likely to occur in the coverall than the gown removal procedure (24). A coverall is commonly used in diseases transmitted through body fluids entering mucus membranes or broken skin, such as Ebola (18). Unlike Ebola, COVID-19 is spread by droplets through the respiratory tract and possibly mucous membranes. Choosing a coverall over a gown should be based on the procedure's conformity since HCWs would need to receive proper training considering the complexity of the procedure. In the technical guidelines released by the government, it is stated that a gown is preferable than a coverall (25). The inconsistency within government guidelines might contribute to the non-uniformity in the healthcare facilities. Considering the drawbacks that outweigh coverall benefits in COVID 19 cases, the WHO recommendation to wear a gown should be preferred. Further investigation is needed to provide recommendations about the type of PPE that allows HCWs to deliver services effectively and safely.

Wearing double gloves is also shown in most videos, which is not recommended by the WHO. Despite the protection the double-gloving seems to offer, the procedure in taking off the gloves in those videos are not conducted properly. Consequently, the coverall doffing step is affected, and the inner clothes become contaminated. Some of the included videos also show the shoe cover and boots worn together, which causes an overlapping function. Shoe-cover functions as a protection so that the worn shoes would not carry the pathogen once the cover is removed. Despite its function, videos that show the use of shoe-cover use it as a replacement of socks worn on bare feet before wearing boots. The WHO recommendation mention wearing boots for cleaners and not HCWs and does not recommend shoe protection (13). Despite this recommendation, a study shows that the swab test on the anterior part of HCWs shoes contains the virus, but cross-contamination from this part is low (26). Moreover, removing the boots or shoe cover could cause body imbalance and risk of self-contamination (24). The Indonesian COVID19 Task Force recommends using boots or shoes with shoe-covers on Level 3 
protection, including surgical and AGPs (21). Thus, the videos' creator might consider adding this part of PPE and perform a rational use of shoe covers or boots.

The unnecessary step of donning PPE is also shown by ten videos that use goggles together with face shield. Eye protection is used to prevent contamination through the mucous membrane. Goggles and face shields are substitutions to one another (27). Wearing both types of eye protection gear is not recommended by WHO. Considering the extra cost caused by this practice, video creators should provide information that the viewer could choose one of the eye protections options instead of wearing both simultaneously. This study has some limitations. Some Youtube videos uploaded by personal accounts have organizational identity attached to it, which could mean that the official organization releases the video. Further study on the official videos that are used for the HCWs training is needed. This study did not investigate the variety of the PPE types used for the COVID19 case in Indonesia. Thus, the underlying conditions that caused this variation need to be studied.

\section{Conclusion}

The steps in donning and doffing PPE in most Indonesian Youtube videos contains errors in the instructions and rational use. The errors showed in the procedures, especially the doffing process, could increase the COVID 19 transmission risk. Since the average number of viewers of these videos is high, it is essential for official accounts to provide videos that show a standard procedure for wearing and removing PPE for COVID 19. The procedures and PPE types in the videos are varied. We recommend the Indonesian government to set a consistent standard and enforce health facilities' conformity. With a large scale of social distancing policy in Indonesia, and the demand for a large number of healthcare workers, videos from open resources such as Youtube could help many healthcare workers gain the skills. Organizations' and institutions' official Youtube accounts could be reliable sources of information, especially for the body's members and staff. Official accounts need to evaluate the procedures shown in the uploaded video and provide the right instruction to protect the healthcare workers and other workers in the near-contact of the COVID-19 patients.

\section{Reference}

1. World Health Organization (WHO). Coronavirus disease 2019 Situation Report 51 11th March 2020. World Heal Organ [Internet]. 2020;2019(March):2633. Available from: https://www.who.int/emergencies/diseases/novel-coronavirus-2019

2. World Health Organization (WHO). Coronavirus: Overview [Internet]. World Health Organization: Health Topics. 2020 [cited 2020 Jun 30]. Available from: https://www.who.int/healthtopics/coronavirus\#tab=tab_1

3. Kementerian Kesehatan Republik Indonesia. Dua Pasien Positif Covid-19 Dirawat di RSPI Sulianti Saroso [Internet]. Kementerian Kesehatan Republik Indonesia: Rilis Berita. 2020 [cited 2020 Jun 30]. Available from: https://www.kemkes.go.id/article/view/20030200009/dua-pasien-positifcovid-19-dirawat-di-rspi-sulianti-saroso.html

4. World Health Organization (WHO). Coronavirus Disease (COVID-19): Situation Report 161. World Health Organization. 2020.

5. Pusparisa Y. Tingkat Kematian Tenaga Kesehatan Indonesia Mencapai 6,5\% [Internet]. Databoks. 2020 [cited 2020 Jun 30]. Available from: https://databoks.katadata.co.id/datapublish/2020/05/15/tingkat-kematian-tenaga-kesehatanindonesia-mencapai-65

6. Gugus Tugas Percepatan Penanganan COVID-19. Pemerintah Siapkan Pengadaan 191.666 APD dalam Penanganan Covid-19 [Internet]. Gugus Tugas Percepatan Penanganan COVID-19: Berita Terkini. 2020 [cited 2020 Jun 30]. Available from: https://covid19.go.id/p/berita/pemerintahsiapkan-pengadaan-191666-apd-dalam-penanganan-covid-19

7. World Health Organization (WHO). COVID-19: How to put on and remove personal protective equipment (PPE) [Internet]. World Health Organization: Course. 2020. Available from: https://openwho.org/courses/IPC-PPE-EN

8. Beydilli H, Serinken M, Eken C, Elicabuk H, Dal O, Acar E, et al. The Validity of Youtube Videos on Pediatric BLS and CPR. Telemed J E-Health Off J Am Telemed Assoc [Internet]. 2016 
Feb;22(2):165-9. Available from:

http:/ / search.ebscohost.com/login.aspx?direct $=$ true $\& d b=$ mdc\&AN $=26308389 \&$ site $=$ ehostlive

9. Barbara L. The use of social media in delivering health information among the Province Health Offices in Indonesia. In: First International Conference on Health Development [Internet]. Jakarta: Universitas Pembangunan Nasional Veteran Jakarta; 2019. Available from: https:// ocs.upnvj.ac.id/index.php/ichd/ichd2019/paper/view/248

10. Yaylaci S, Serinken M, Eken C, Karcioglu O, Yilmaz A, Elicabuk H, et al. Are Youtube videos accurate and reliable on basic life support and cardiopulmonary resuscitation? EMA - Emerg Med Australas. 2014;26(5):474-7.

11. World Health Organization (WHO). Steps to put on personalprotective equipment (PPE) including coverall [Internet]. Genevaw PP - Genevaw: World Health Organization; 2015. Available from: https://apps.who.int/iris/handle/10665/150116

12. Kilinc FS. A Review of Isolation Gowns in Healthcare: Fabric and Gown Properties. J Eng Fiber Fabr. 2015;10(3):155892501501000.

13. World Health Organization (WHO). Rational use of personal protective equipment for coronavirus disease 2019 ( COVID-19). Who. 2020;2019(February):1-7.

14. Chughtai AA, Seale H, Macintyre CR. Availability, consistency and evidence-base of policies and guidelines on the use of mask and respirator to protect hospital health care workers: A global analysis. BMC Res Notes. 2013;6(1):1-9.

15. Lim SM, Cha WC, Chae MK, Jo IJ. Contamination during doffing of personal protective equipment by healthcare providers. Clin Exp Emerg Med. 2015;2(3):162-7.

16. Phan LT, Maita D, Mortiz DC, Weber R, Fritzen-Pedicini C, Bleasdale SC, et al. Personal protective equipment doffing practices of healthcare workers. J Occup Environ Hyg [Internet]. 2019;16(8):575-81. Available from: https://doi.org/10.1080/15459624.2019.1628350

17. Mumma JM, Durso FT, Casanova LM, Erukunuakpor K, Kraft CS, Ray SM, et al. Common Behaviors and Faults When Doffing Personal Protective Equipment for Patients with Serious Communicable Diseases. Clin Infect Dis. 2019;69(Suppl 3):S214-20.

18. Honda H, Iwata K. Personal protective equipment and improving compliance among healthcare workers in high-risk settings. Curr Opin Infect Dis. 2016;29(4):400-6.

19. Verbeek J, Rajamaki B, Ijaz S, Sauni R, Toomey E, Blackwood B, et al. Personal protective equipment for preventing highly infectious diseases due to exposure to contaminated body fluids in healthcare sta (Review). Cochrane Database Syst Rev. 2020;4:1-147.

20. World Health Organization. Steps to put on personal protective equipment (PPE) including coverall Internet]. Infographic. Geneva PP - Geneva: World Health Organization; 2007. Available from: https://www.who.int/publications/i/item/steps-to-put-on-personal-protective-equipment-(ppe)-including-coverall

21. Gugus Tugas Percepatan Penanganan COVID-19. Standar APD (Alat Pelindung Diri) untuk Penanganan COVID-19 di Indonesia [Internet]. 2020. Available from: https:// covid19.go.id/p/protokol/rekomendasi-standar-penggunaan-apd-untuk-penanganancovid-19-di-indonesia-revisi-1

22. Centers for Disease Control and Prevention. Strategies for Optimizing the Supply of Isolation Gowns [Internet]. 2020. Available from: https://www.cdc.gov/coronavirus/2019-ncov/hcp/ppestrategy/isolation-gowns.html

23. Public Health England. Guidance: COVID-19 personal protective equipment (PPE) [Internet]. 2020. Available from: https://www.gov.uk/government/publications/wuhan-novel-coronavirusinfection-prevention-and-control/covid-19-personal-protective-equipment-ppe

24. Suen LKP, Guo YP, Tong DWK, Leung PHM, Lung D, Ng MSP, et al. Self-contamination during doffing of personal protective equipment by bealthcare workers to prevent Ebola transmission. Antimicrob Resist Infect Control. 2018;7(1):1-9.

25. Direktorat Jenderal Pelayanan Kesehatan. Petunjuk Teknis Penggunaan Alat Perlindungan Diri (APD) dalam Menghadapi Wabah COVID 19 DIREKTORAT [Internet]. Jakarta; 2020. Available from: https:// covid19.go.id/p/panduan/petunjuk-teknis-penggunaan-alat-perlindungan-diri-apddalam-menghadapi-wabah-covid-19 
26. Ong SWX, Tan YK, Chia PY, Lee TH, Ng OT, Wong MSY, et al. Air, Surface Environmental, and Personal Protective Equipment Contamination by Severe Acute Respiratory Syndrome Coronavirus 2 (S ARSCoV -2) from a Symptomatic Patient. JAMA - J Am Med Assoc. 2020;323(16):1610-2.

27. National Institute for Occupational Safety and Health (NIOSH). Eye safety: Infection control [Internet]. Centers for Disease Control and Prevention. 2013 [cited 2020 Jun 28]. Available from: https://www.cdc.gov/niosh/topics/eye/eye-infectious.html 